\title{
低形成大動脈弁尖と大動脈壁の癒合による 左冠血流障害に対する外科手術
}

\author{
小森 悠 矢* 和 田 直 樹* 加部東 直広* 桑 原優 大* 高 橋 幸 宏*
}

\begin{abstract}
症例は 4 歳 10 カ月男児, 出生時心疾患の指摘なし. 4 歳 3 カ月時, 停留精巣の手術の際, 啼泣後に ST 低下 を伴う心電図変化が続き精査の方針となった。心蔵カテーテル検査では，心機能は良好，有意な大動脈弁逆 流も認めなかったが，左冠尖の低形成を認めた。大動脈造影では，左冠動脈への順行性血流がそしく，右冠 動脈からの側副血管により逆行性に造影されていた。造影された左冠動脈自体には狭窄がなく，入口部に造 影剤の貯留を認めていたため, 弁尖による冠血流流入障害を考え, 無症状ではあったが手術の方針となっ た. 術中所見では，低形成の左冠尖が左バルサルバ洞を覆い隠すように大動脈壁に付着していることで，左 冠動脈入口部への冠血流の流入障害を引き起こしていた。大動脈離断部から左冠動脈入口部直上にかけて パッチで拡大した，術後経過は良好であり，術当日に抜管した。翌日には ICU を退室した. 術後経胸壁心 エコーでは心機能は良好で, 有意な大動脈弁逆流も認めず, 左冠動脈の順行性血流も確認できた. P0D11 に退院した。術後半年で行った心臓カテーテル検査でも大動脈弁逆流は認めず，左冠動脈には有意な狭窄は なく，右冠動脈からの逆行性血流も消失していた。稀少な症例を経験したので報告する. 日心外会誌 50 巻 4 号 : 244-247 (2021)

キーワード：冠血流障害；低形成大動脈弁尖 ; 弁尖癒合
\end{abstract}

Surgical Treatment for Occlusion of Left Coronary Artery Ostium by an Aortic Valve Cusp Yuya Komori*, Naoki Wada*, Naohiro Kabuto*, Yuta Kuwahara* and Yukihiro Takahashi* (Sakakibara Heart Institute, Pediatric Cardiovascular Surgery*, Tokyo, Japan)

The patient was a 4-year-old boy, with no indication of heart disease at birth. When he was 4 years and 3 months old, he underwent surgery for cryptorchidism, and persistent changes after crying, consisting of ST-segment depression, were noted on the ECG. Therefore, it was decided that a detailed examination would be carried out. Aortography revealed that a small left coronary cusp had formed a pouch and that there was a delayed washout of the contrast material in the left coronary artery compared with the right coronary artery. Right coronary angiography showed retrograde flow to the left coronary artery. There was no significant aortic regurgitation, and no stenosis in the left coronary artery. Intraoperative findings demonstrated that the hypoplastic left coronary cusp had adhered to the aortic wall and covered the left sinus of Valsalva. Enlargement of the Valsalva was performed by placing a patch from the aortic transection site to an area directly above the coronary artery ostium. Postoperatively, the patient recovered satisfactorily and was discharged on the eleventh postoperative day. Cardiac catheterization performed 6 months after surgery showed no aortic regurgitation, no significant stenosis in the left coronary artery, and no retrograde flow from the right coronary artery. We report our experience with the rare case described above. Jpn. J. Cardiovasc. Surg. 50:244-247 (2021)

Keywords : coronary ostium occlusion; hypoplastic aortic valve ; aortic valve fusion

大動脈弁尖による冠動脈の狭窄は，報告が散見される程 度で非常に稀である ${ }^{1,2)}$ その多くは大動脈弁尖と大動脈 壁の癒合によるもので, 弁尖の切除, 弁置換などを行うこ とで閉塞の解除が行われている ${ }^{3)}$. 今回, 低形成の左冠尖 が原因で，冠血流流入障害を来しているが，弁尖温存のま
ま狭窄の解除を行うことができた症例を経験したため報告 する.

症例

患者 : 4 歳 10 力月, 男児, 体重 $13.42 \mathrm{~kg}$, 身長 $97.4 \mathrm{~cm}$.
2021 年 1 月 6 日受付, 2021 年 3 月 13 日採用

Corresponding author: Yuya Komori

Sakakibara Heart Institute, Pediatric Cardiovascular Surgery,

Tokyo, Japan

* 榊原記念病院小児心臓血管外科

干 183-0003 東京都府中市朝日町 3-16-1
本研究において一切の利益相反や研究資金の提供はない. None of the authors of this manuscript has any financial or personal relationship with other people or organizations that could inappropriately influence their work. 
診断 : 大動脈弁形成不全・左冠血流障害.

既往歴: 停留精巣術後 (4 歳 3 力月).

現病歴：在胎 38 週， $2,800 \mathrm{~g}$ で出生. 心疾患に関する指 摘はなく, 自覚症状も認めていなかった。

前医にて, 上記停留精巣手術時の激しい啼泣後に I, aVL，II，III，aVF，V2-V6 で ST 低下あり。術後も心電図 異常が数時間以上持続したため, 心筋シンチを施行すると 左室前壁の負荷血流低下あり。藏カテーテル検査を含め た精查が施行され，手術目的に当院紹介となった。

経胸壁心エコー：左室長軸像では左室拡張末期径は 36 $\mathrm{mm}$ ，左室収縮末期径 $26 \mathrm{~mm}$ ，心室中隔厚 $4.9 \mathrm{~mm}$ ，左室 後壁厚 $4.5 \mathrm{~mm}$. 左室駆出率 $61.6 \%$ で心収縮は良好だった。 大動脈弁は開放良好で，3 尖だが左冠尖（LCC）は小さ かった。大動脈弁最大流速 $1.9 \mathrm{~m} / \mathrm{s}$, 平均圧較差 6.7 $\mathrm{mmHg}$ であり, 大動脈弁・弁上の狭窄は認めなかった。 大動脈弁逆流 (AR) は軽度〔LCC と右冠尖 (RCC) 交連 部から LCC 方向へ]で，その他有意な肺動脈弁逆流・房 室弁逆流も認めなかった。大動脈弁輪径は $12 \mathrm{~mm}$, 肺動 脈弁輪径は $11.5 \mathrm{~mm}$ だった。

心臓カテーテル：左室駆出率は $69.1 \%$ 心収縮は良好. 大動脈弁逆流は Sellers 分類で I 度, LCC は形態的に低形 成と考えられ，左冠動脈（LCA）へのカテーテルの挿入は 困難だった．LCAの血流は右冠動脈（RCA）から側副血 管を経由し逆行性に造影されており，左バルサルバ洞は ポーチ状となり造影剤の貯留を認めていた。 (Fig. 1a, b, c)

造影 CT ：RCC と無冠尖（NCC）は同定できるが LCC は同定できず，低形成が疑われた，LCAの起始部は不明 瞭だったが，大動脈弁上に狭窄は認めていなかった。

手術所見：胸骨正中で切開した。上行大動脈に狭窄所見 はなかった.上行大動脈送血, 上下大静脈脱血にて体外循 環を確立した。 心停止とし， RCAの $5 \mathrm{~mm}$ 上で大動脈を 離断した。大動脈弁は LCC が低形成で短縮し，LCA の開 口部を覆うようにバルサルバ洞へ付着していたが，弁尖の 性状は良好であった。

LCA 開口部自体は 3 $4 \mathrm{~mm}$ 程度あり, ゾンデで検索し ても開口部・内径は保たれていたため，LCA 自体の拡大 は行わない方針とした.

LCA 直上のバルサルバ洞を切開, 交連間距離のバラン スを考慮し，弁の変形を来さないサイズにウシ心膜パッチ で拡大した。パッチの材質に関しては，そのハンドリング の良さと，これまで大動脈基部への同様の使用で石灰化に 対する明らかな問題を経験していないため, ウシ心膜パッ チを選択した。

拡大後，LCA の開口を確認し大動脈を閉鎖した（手術 時間：1 時間 45 分, 体外循環時間 : 52 分, 大動脈遮断時 間 : 34 分).

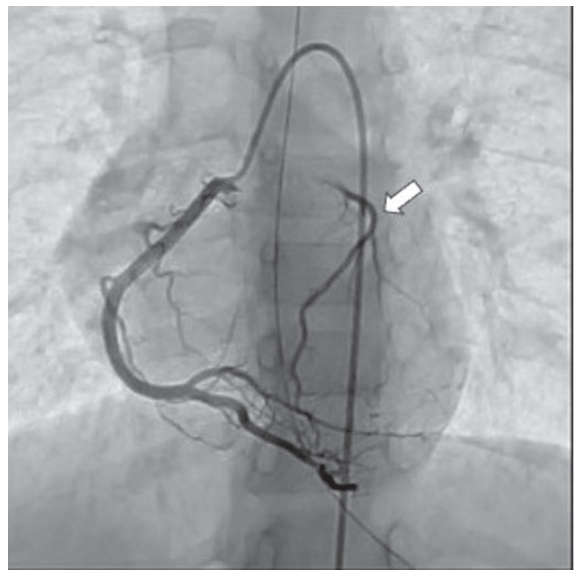

( a )

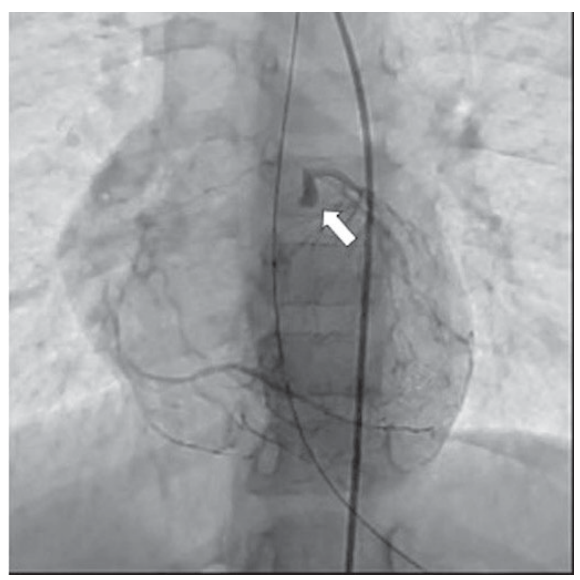

( b )

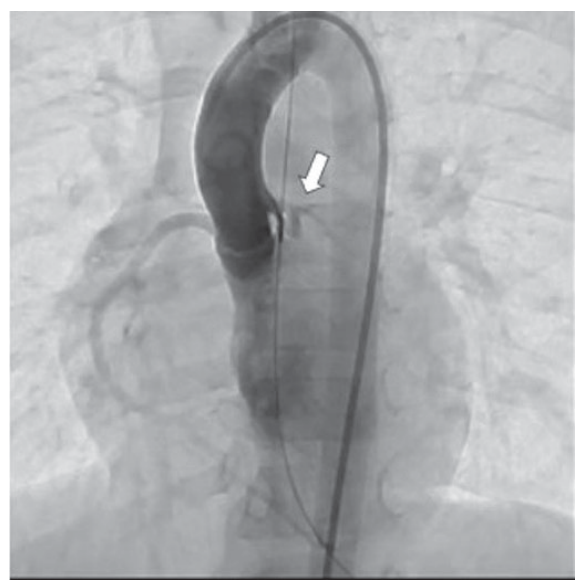

( c)

Fig. 1

(a) Preoperative Right Coronary Angiogram (RCAG) 1. § : Coronary angiogram showing retrograde flow through the right coronary artery to the left coronary. (b) Preoperative RCAG 2. i: Coronary angiogram showing that the hypoplastic left coronary cusp fused to the aortic wall, forming a pouch. (c) Preoperative Aortogram $(\mathrm{AoG})$. There was no evidence of supravalvular aortic stenosis. During cardiac catheterization, the left coronary (LC) ostium could not be cannulated. $§$ : Aortogram showing no antegrade flow of the left coronary artery. 


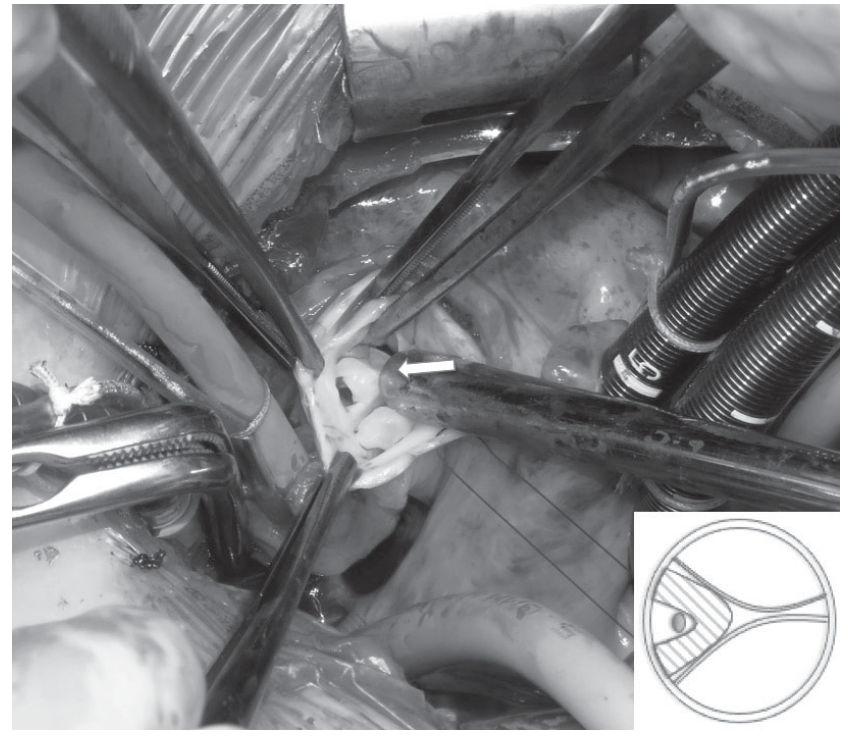

( a )

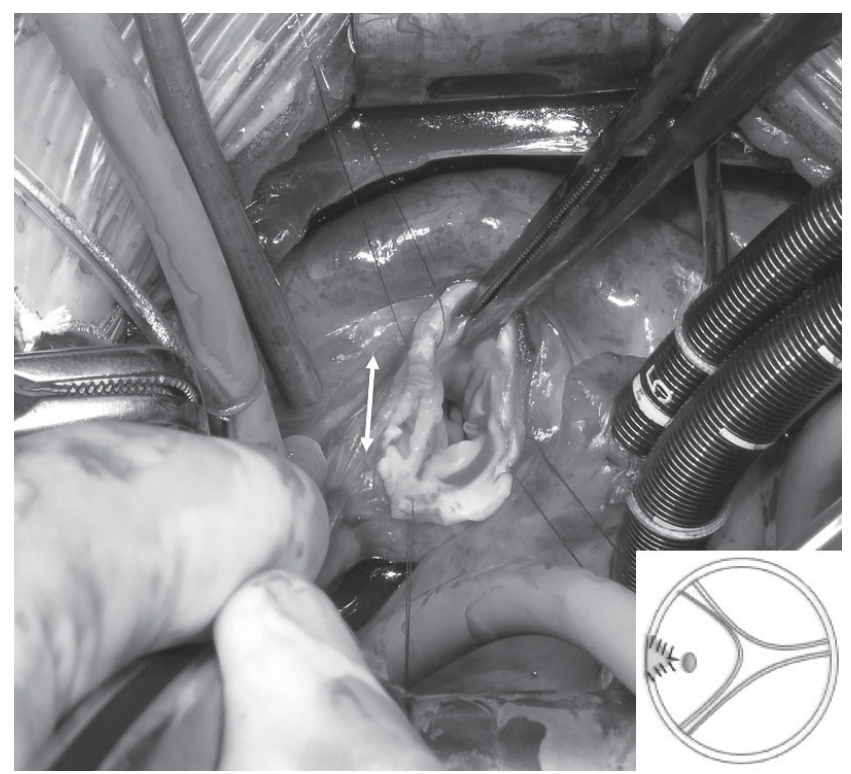

( b )

Fig. 2

(a ) $\diamond$ : The hypoplastic left coronary cusp adhered to the aortic wall and formed a pouch with a tiny slit. ( $b$ ) An orifice of the left coronary artery was observed after incision of the pouch. A bovine pericardial patch was implanted into the aorta.

体外循環離脱はスムーズで，心機能の低下は認めなかっ た (Fig. 2a, b).

術後経過：術当日夜間に抜管した。術翌日にICUを退 室した。術後経胸壁心エコーでは心収縮良好であった。 AR は軽度で増悪はなかった。経過良好で POD11に退院 した。術後半年で行った心臓カテーテル検査（Fig. 3a, b, c）では, LCA は大動脈から順行性に造影され, 狭窄所見 も認めなかった。また， RCA から LCA への逆行性の造影 も認めず，ARも I 度で増悪はなかった。

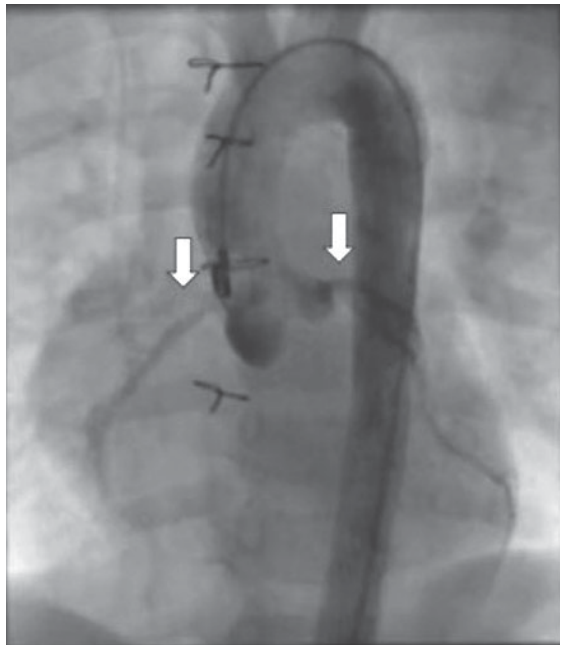

( a )

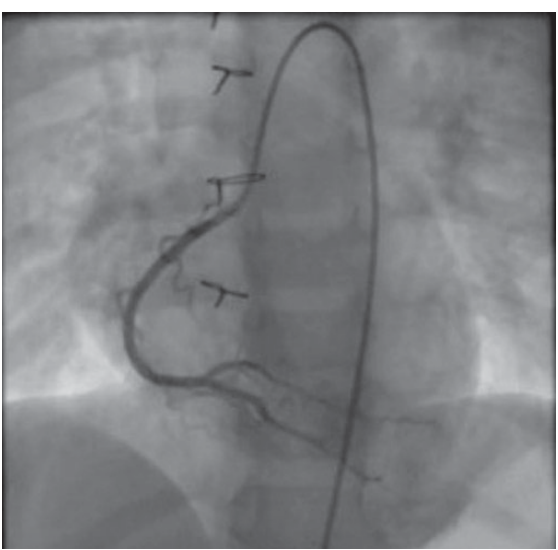

( b )

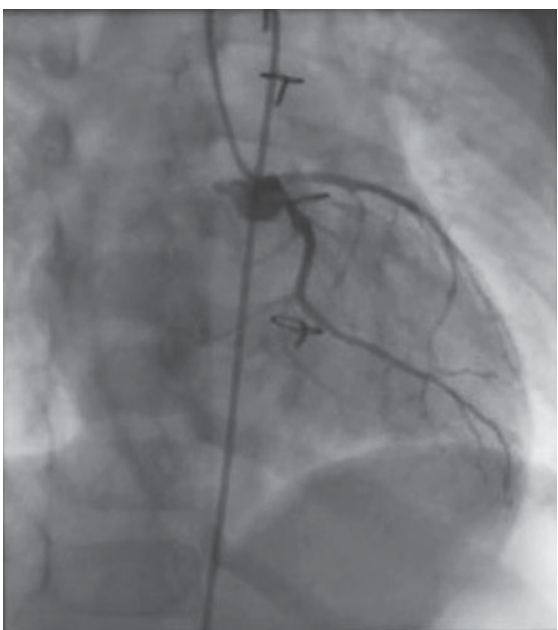

(c)

Fig. 3

(a) Postoperative AoG. \: Coronary angiogram showing antegrade flow. (b ) Postoperative RCAG. No retrograde flow through the right coronary artery to the left coronary. (c) Postoperative left coronary angiogram. After the operation, the left coronary (LC) ostium could be cannulated during cardiac catheterization. 


\section{考察}

大動脈弁尖自体が原因となる冠血流障害は非常に稀であ り, 半数, あるいはそれ以上に大動脈弁上狭窄を合併して いるという報告もある ${ }^{4,5)}$.

これらの症例の原因としては大動脈弁尖の先天的形成異 常の他に, 感染後の 2 次性変化によるものや, 大動脈炎症 候群なども指摘されている ${ }^{2)}$ が，本症例では感染の既往は なく, 術中にも弁尖に炎症性の変化や血栓などは認めな かった. 冠状動脈造影では造影剤ウォッシュアウトの遅延 と, ポーチの形成が特徴的であるが, これらのほとんどは 形成不全の大動脈弁が関与していることが示唆されてい る. 低形成弁尖が弁の周りに乱流を形成し, 弁尖と大動脈 壁の間に線維組織の形成を誘発し, 弁尖と大動脈壁の付着 が起こるという機序が指摘されており, 同様のメカニズム で狭窄を起こした症例も報告されている ${ }^{6)}$.

また，原因は不明であるが成人期に発見されたものには 狭心症状などがあるにもかかわらず，小児期ではほとんど の症例において無症状であることが報告されている ${ }^{1,2,4,6)}$. 当症例でも無症状であり，他の手術時に偶発的に発見され ていた。ただし，小児期に無症状であったとしても，成人 の症例に関する以前の報告では当疾患に関する死亡率が高 いことを示されており，比較的短期間で進行し，心筋虚血 と突然死を引き起こす可能性があることも報告されてい $る^{7)}$.

したがって, 診断がついた時点で早期の外科的治療を検 討する必要があると考える。

術式に関しては, 大動脈弁の性状, 冠動脈口の狭窄の程 度により異なり，それによって治療方針も工夫されてい る. 具体的には, 弁尖と大動脈壁との癒合が高度で, 弁機 能の維持が困難な場合には弁置換, Ross 手術などが行わ れている。また, 冠動脈壁まで狭窄が及ぶ場合には, 内胸 動脈壁などを用いた左冠動脈主幹部のパッチ拡大などが報 告されている2,4,6,7).

本症例に打いても弁尖の性状次第では, 弁輪拡大を伴う 弁置換や, 性状とバランスに大きな問題がない肺動脈弁を 使用しての Ross 手術も考慮して手術へと臨んだが, LCC
は低形成ではあるものの性状は問題なく, $\mathrm{NCC} \cdot \mathrm{RCC}$ と の接合も保たれており ARも認めていなかったため弁尖は そのまま温存可能と判断した。

また，冠動脈口は $3 \mathrm{~mm}$ 程度で内径が保たれており，冠 動脈入口部と, LCA 自体の拡大の必要はないと判断した。

狭い LCC の両交連間のバルサルバ洞をパッチ拡大する ことで, 弁尖と大動脈によるポーチ形成は解除され, 冠血 流の流入は改善された. 術後の ARの指摘もなく, 経過は 良好と考える。

\section{結 語}

大動脈弁尖による冠動脈口の狭窄は稀ではあるが, 発見 された時点で手術を考慮する必要がある。また, 術式は弁 尖の性状や弁輪径, 冠動脈の形態などから総合的に判断を するが，その条件次第では本症例のように弁尖を温存でき ることもあり, 術前検査も含め十分に検討する必要があ る.

\section{文献}

1) Washiyama N, Kazui T, Takinami M et al. Aortic regurgitation with dilation of ascending aorta and right coronary artery occlusion by a rudimentary aortic cusp. Ann Thorac Surg $2001 ; 72: 919-21$.

2) Waxman MB, Kong Y, Behar VS et al. Fusion of the left aortic cusp to the aortic wall with occlusion of the left coronary ostium, and aortic stenosis and insufficiency. Circulation $1970 ; 41: 849-57$.

3) Hioki H, Urata $Y$, Sato $T$ et al. Aortic stenosis and regurgitation with aortic subannular left ventricular diverticulum and occlusion of the right coronary ostium by the bicuspid aortic valve. J Cardiovasc Surg 2019 ; 48 : 234-8.

4) Kalimi R, Palazzo RS, Graver LM. Occlusion of left coronary artery ostium by an aortic valve cusp. Ann Thorac Surg $2000 ; 69: 637-9$.

5) Kurosawa H, Wagenaar SS, Becker AE. Sudden death in a youth. A case of quadricuspid aortic valve with isolation of origin of left coronary artery. Br Heart J 1981 ; 46 : 211-5.

6) Amrani M, Rubay J, Pirenne B et al. Isolation of the coronary artery ostium by an aortic cusp attachment: a rare cause of myocardial ischemia. Eur J Cardiothorac Surg 1994; 8 : 663-4.

7) Yashima M, Takeuchi T, Watanabe N et al. Stenosis of left coronary artery ostium by a hypoplastic cusp. Kyobu Geka $2009 ; 62: 354-7$. 